\title{
The Effects of Service Payment Retardation from National Health Insurance Claim to the Employee's Work Motivation According to Theory of Frederick Hezberg in the Hospital
}

\author{
Nita Indah Lestari ${ }^{1}$, Sri Hernawati ${ }^{2}$, Sebastiana Viphindrartin ${ }^{3}$ \\ ${ }^{1}$ Graduate Student, Magister Program of Public Health Education, Jember University, East Java (Indonesia), \\ ${ }^{2}$ Medical Doctor, Faculty of Dentistry, Jember University, East Java (Indonesia), ${ }^{3}$ Economics Lecturer,Faculty of \\ Economics and Business, Jember University, East Java (Indonesia)
}

\begin{abstract}
Introduction: In era of National Health Insurance, the number of insurance participants was in increase and recorded approximately about 203,28 million (77\%) from the total population of Indonesia, this condition affected to the invoice amount which must be paid by Social Insurance Administration Organization (BPJS) to the related hospital which partnered with this organization. The implementation of this deal delivered to good effects from either the hospital or related organization ${ }^{(11)}$. In Jember, it was indicated retardation or delay of service payment in certain hospitals. The retardation of service payment was very influential to the work motivation of employee which affected to the quality of service, the employee motivation was very significant to build quality performance for the employee. The accurate illustration which depicted this relation was that the motivation could raise high work satisfaction on employee, this condition was realized if the employee's expectation and need could be realized in both material and non-material, if those were fulfilled, then their work motivation would be built. The objective of this research was to analyze the effects of service payment retardation from National Health Insurance claim to the motivation of employee based on Frederick Hezberg's theory in RSD Balung.
\end{abstract}

Method: This research was included into quantitative research which exerted cross sectional research method. The total population of this research were all employees in RSD Balung Jember District, specifically in about 157 respondents. The method of data sampling was stratified random sampling according to the level within this research population. The total sample of this research was 60 respondents ${ }^{(15)}$. Further, the data collection was employed through questionnaire and was then analyzed through ordinal regression. Based on the research finding, it showed effects between service payment retardation from National Health Insurance claim to the employee's motivation accordingly to theory of Frederic Hezberg.

Keywords: Service Payment Retardation, Motivation, Theory of Frederick Hezberg.

\section{Introduction}

Research Background: The government attempts to implement Universal Health Coverage gradually by

\section{Corresponding Author:}

\section{Dr. Drg. Sri Hernawati}

M. Kes. Medical Doctor, Faculty of Dentistry, University of Jember, Jawa Timur (Indonesia).

Phone No.: 08123458242

e-mail: srihernawati.drg5@yahoo.com issuing program of National Health Insurance (JKN), which is managed by Social Insurance Administration Organization (BPJS). In the era of National Health Insurance, the participants of this program keep increasing since 2018, it was recorded in about 203,28 million (77\%) from the total population in Indonesia ${ }^{(14)}$. The increase of JKN participant number in many hospitals impacts to the huge amount of invoice which must be paid by Social Insurance administration Organization (BPJS). The retardation of service payment in some hospitals is also occurred in Jember. This retardation of 
health service payment is very influential to the work motivation of employee which then impacts to the quality of health service, the employee's motivation is regarded as very significant to realize quality performance for the employee ${ }^{(3)}$. The accurate image which can depict this relation is that the motivation can create high work motivation, this condition can be realized if the employee's expectation and need are fulfilled well in both material and non-material, then, it will raise to their work motivation ${ }^{(2)}$.

The motivation is a whole process of encouragement or stimulation which given to the employee to have willingness in work sincerely without any forms of compulsion, moreover, the organization will be able to perform all programs if the employee within this organization are successful to do their tasks well according to their field and responsibility ${ }^{(13)}$.

The theory of work satisfaction explains that the aspect which motivates work motivation of employee in order to fulfill their need in both material and nonmaterial satisfaction. This aspect is considered as reward given to the employee ${ }^{(4)}$.

The purpose of motivation is to develop work satisfaction on employee ${ }^{(1)}$. The factor of motivator can raise the work satisfaction. Moreover, the theory of work motivation and satisfaction have been demonstrated by many experts. The theory of motivation from Hezberg has asserted two factors which can influence work motivation on employee in order to create their work satisfaction, as they are factor of motivator and factor of hygiene. The factor of motivator is consisted of achievement, recognition, the work itself, responsibility, advancement, the possibility of growth. Next, the factor of hygiene is consisted of work situation, wage or compensation, relation with co-worker and work safety. The implementation of motivator and hygiene factor in an organization can boost the improvement of employee's work satisfaction, thus, it is summed that the individual will feel satisfied and motivated if they have accepted appreciation (salary, incentive and allowance) ${ }^{(10)}$.

In Jember, the service payment in several hospitals from JKN claim has been in retardation or delay, including to a hospital in Balung since 2018-2019. This situation is affected by a number of factors as internal and external factor. The internal factor is the factors which can occur in the hospital, for instance administration process of claim submission as well as lack of claim document files. The external factor is the factor might be raised from related parties of BPJS which go through certain budget deficit.

The research finding by NurFadhila \& Syahrir (2017) has stated that the level of employee's satisfaction regarding to the service becomes an indicator to indicate how far the success of service which has been offered by Social Insurance Administration Organization (BPJS). The service is related to the work satisfaction. Moreover, the work satisfaction cannot be separated from work motivation which is frequently the expectation of employee $^{(3)}$.

Based on those backgrounds, the researchers are interested to identify the effects of service payment retardation from National Health Insurance (JKN) claim to the employee's motivation based on theory of Frederick Hezberg.

\section{Method}

This research was included into a quantitative research which employed cross sectional research design. This research was conducted in RSD BalungJember. The research and data analysis was started in December 2019 - January 2019. The population in this research were all employees of RSD BalungJember District in approximately 157 respondents. The method of data sampling was slovin formula which was then presented per profession of health officer or non-health officer through lemeshowformula, it was resulted to 60 respondents. The variable of research was consisted of independent variable as retardation of service payment from JKN claim, while the dependent variable was employee's motivation according the theory proposed by Frederick Hezberg. The instrument of data collection in this research was questionnaire. The result of data collection was then analyzed by exerting ordinal regression method. Further, this research has been tested ethically in ethics commission of health research of Faculty of Dentistry, University of Jember in regulation number 583/UN25.8/KEPK/DL/2019.

Findings: The research data was analyzed through ordinal regression and presented in two sections. The first section was general data, while the second was specific data of research. 


\section{General Data:}

Table 1. Respondent Characteristics

\begin{tabular}{|c|c|c|c|}
\hline Respondent Characteristic & Clarification & Number (n) & Percentage (\%) \\
\hline \multirow{3}{*}{ Gender } & Male & 23 & $38,3 \%$ \\
\hline & Female & 37 & 61,7 \\
\hline & Total & 60 & 100 \\
\hline \multirow{5}{*}{ Age } & 21-30 Years Old & 19 & 31,7 \\
\hline & 31-40 Years Old & 25 & 41,7 \\
\hline & 41-50 Years Old & 8 & 13,3 \\
\hline & $>50$ Years Old & 8 & 13,5 \\
\hline & Total & 60 & 100 \\
\hline \multirow{6}{*}{ Employment Status } & Civil Servant (PNS) & 9 & 15,0 \\
\hline & Internship & 20 & 33,3 \\
\hline & Contract & 12 & 20,0 \\
\hline & Temporary Worker (PTT) & 12 & 20,0 \\
\hline & Others & 7 & 11,7 \\
\hline & Total & 60 & 100 \\
\hline \multirow{6}{*}{ Educational Background } & Senior High School & 7 & 11,7 \\
\hline & Diploma 1/II/III/IV & 26 & 43,3 \\
\hline & Bachelor & 17 & 28,3 \\
\hline & Magister & 3 & 5,0 \\
\hline & Others & 7 & 11,7 \\
\hline & Total & 60 & 100 \\
\hline \multirow{3}{*}{ Marriage Status } & Married & 31 & 51,7 \\
\hline & Unmarried & 29 & 48,3 \\
\hline & Total & 60 & 100 \\
\hline
\end{tabular}

Based on the table, it referred that the total who involved in this research were 60 respondents, approximately $11,7 \%$ or as many as 7 respondents were the graduate of Senior High School, 43,3\% or as many as 26 respondents were graduate of Diploma Program I/II/III/ IV , 28,3\% or as many as 3 respondents were graduate of Magister Program and $11,7 \%$ or as many as 7 respondent were from various educational backgrounds. The age of employee in RSD BalungJember District was in range of $21-30$ years old $31,7 \%$ or as many as 19 respondents, the age range between $31-40$ years old $41,7 \%$ or as many as 25 respondents, the age range between $41-50$ years old $13,3 \%$ or as many as 8 respondents and the age range $>50$ years old $13,5 \%$ or as many as 8 respondents. The total of respondents in employment status of Civil Servant (PNS) $15,0 \%$ or as many as 9 respondents the employment status of internship $33,3 \%$ or as many as 20 respondents, the employment status of work contract $20,0 \%$ or as many as 12 respondents, the employment status of temporary worker (PTT) $20,0 \%$ or as many as 12 respondents and other employment status $11,7 \%$ or as many as 7 respondents. Furthermore, the employee in RSD Balung in marriage status of married $51,7 \%$ or as many as 29 respondents, while unmarried status $48,3 \%$ or as many as 29 respondents. 
Specific Data:

Table 2. Analysis on Service Payment Retardation from National Health Insurance (JKN) Claim

\begin{tabular}{|l|l|c|c|}
\hline Category & Clarification & Number (n) & Percentage (\%) \\
\hline Retardation of Service Payment from JKN Claim & Retarded & 52 & 86,7 \\
\hline Total & On Time & 8 & 13,3 \\
\hline
\end{tabular}

Based on the table, it indicated that from the total of 60 respondents, $86,7 \%$ or respondents or as many as 52 respondents were late or retarded and $13,3 \%$ or as many as 8 respondents were stated as on time in their health service payment.

Table 3. Employee's Work Motivation in RS Balung

\begin{tabular}{|l|l|c|c|}
\hline Category & Clarification & Number (n) & Percentage (\%) \\
\hline Work Motivation & Less Motivated & 35 & 58,3 \\
\hline & Fairly Motivated & 18 & 30,0 \\
\hline Total & Motivated & 7 & 11,7 \\
\hline
\end{tabular}

Based on the table, it demonstrated that from 60 respondents, $58,3 \%$ or as many as 35 respondents were less motivated, $30,0 \%$ or as many as 18 respondents were fairly motivated and $11,7 \%$ or as many as 7 respondents were considered as motivated.

Table 4. Cross Tabulation on Service Payment Retardation from National Health Insurance (JKN) Claim towards employee's Work Motivation

\begin{tabular}{|c|c|c|c|c|}
\hline Work Motivation & \multirow{2}{*}{ Motivated } & \multirow{2}{*}{ Fairly Motivated } & \multirow{2}{*}{ Less Motivated } & \multirow{2}{*}{ Tota } \\
\hline Retardation of Service Payment from JKN Claim & & & & \\
\hline On Time & 5 & 2 & 1 & 8 \\
\hline Retarded or Late & 2 & 16 & 34 & 52 \\
\hline Total & 7 & 18 & 35 & 60 \\
\hline
\end{tabular}

The table 4 has explained the result of data analysis which employed ordinal regression method in order to analyze the effects of service payment retardation from National Health Insurance (JKN) claim to the employee's work motivation. Moreover, the result of data analysis showed that $\mathrm{p}$ value $(0,000) \alpha(0,05 \%)$ which was referred the effects of service payment retardation from National Health Insurance (JKN) claim to the employee's work motivation.

\section{Discussion}

The research finding referred the effects between retardation of health service payment from National
Health Insurance (JKN) claim and employee's work motivation in RS Balung, which particularly resulted to the $p$ value $0,000(<0,05)$. The appreciation in form of salary was the most complex task for the hospital in work environment, meanwhile it was the significant aspect for the employee, since the amount of salary and its punctuality in salary or wage payment would reflect the measurement of their performance among employees, families and society, while it was also significant for the behalf of hospital itself, because it would reflect the hospital attempt to maintain the human resource in order to build high loyalty and commitment in the hospital. Moreover, the motivation was a form 
of support which functioned to stir the employee to be able to develop their performance, so they could realize and pursue the purpose of hospital ${ }^{(8)}$. The motivation was very important for the employee, because it was an aspect which affected, distributed and supported human behavior to be able to work with enthusiasm in order to achieve optimal result ${ }^{(12)}$. The accurate image which could illustrate this relation was that the motivation was able to raise high work satisfaction on the employee, this situation could be realized if the employee's expectation and need was fulfilled in both material and non-material, then it would build work motivation on them ${ }^{(7)}$.

The purpose from this motivation was to improve work motivation on the employee. The factor of motivator could build work satisfaction. Further, the theory of motivation and satisfaction has been asserted by many experts. Those theories would keep developing, especially in sector of psychology, human resource management and organizational behavior. The implementation of work was very affected by an important factor, hygiene factor. The factor of hygiene was aimed to maintain the level of work motivation on employee, if this factor was given properly. But, if this factor was given improperly, it would impact to the decrease of enthusiasm and work performance of employee $^{(6)}$.

The motivation which given to the employee was not that easy, since the organization must firstly consider several factors which could influence the employee's work motivation. The theory of motivation from Hezberg has asserted two factors which could influence the employee's work motivation in order to create their work satisfaction, as factor of motivator and factor of hygiene. The factor of motivator was consisted of achievement, recognition, the work itself, responsibility, advancement and the possibility of growth. While, the factor of hygiene was comprised of work condition, salary or compensation, relation with co-workers and work safety. Next, the implementation of both factors of motivator and hygiene in an organization could encourage the improvement of employee's work satisfaction, therefore, it was concluded that the individual would feel satisfied and motivated if their received appropriate form of appreciation (salary, incentive and allowance) ${ }^{(5)}$.

The practice of motivator factor in an organization was able to encourage the improvement of employee's work satisfaction, then, it was summed that the individual would feel satisfied and motivated if they received appreciation form the organization (salary, incentive and allowance). Reversely, the factor of hygiene would cause individual unmotivated in work, since the purpose of motivation was to improve the work satisfaction on employee $^{(9)}$.

\section{Conclusions}

Based on the research findings, it was concluded that this research studied about the effects of service payment retardation from National Health Insurance (JKN) claim to the employee's work motivation in the hospital. According to the data analysis in this research, it was found that the retardation of service payment could affect to the work motivation of employee in the hospital, moreover, the purpose of this motivation delivery was to improve the employee's work satisfaction.

This research also explored the causal factors of employee's work motivation, especially in the work area of hospital. Based on this research, the researchers suggested the next researchers to study this similar research focus in deeper, particularly on the factors which cause unmotivated individual either in direct or indirect.

\section{Conflict of Interest: None}

\section{Source of Funding: Self}

Ethical Clearance: This research has undergone ethical test in ethics commission of health research of Faculty of Dentistry, University of Jember in this following registration number 690/UN25.8/KEPK/ DL/2019.

\section{References}

1. Alim MB. Teori Hezberg dan Kepuasan Kerja Karyawan. Health Nation. 2018:1 (1). http:// repository.unej.ac.id/handle/1234567/858

2. Aziz AR, Tjahja H. Hubungan Antara Besar Jasa Pelayanan BPJS Dengan Tingkat Kepuasan Kerja Dalam Memberikan Pelayanan Kesehatan Di Puskesmas Mojoworno Jombang. Jurnal Keperawatan STIKES Pemerintah Kabupaten Jombang. Science Journal of Nursing. 2015; 1(2): 38-43. http://journal. stikespemkabjombang. ac.id/ index. php/jikep/article/view/37

3. Fadhila N, Syahrir A, et.al . Job Satisfaction of Medical Workers in the Era of National Health Insurance (JKN). Jurnal of Publick Health.2017; 
2(3): 25-4. http:dx.doi.org/10.30597/mkmi. V14i2.4531

4. Hamzah B. Uno M. Teori Motivasi dan Pengukuran. Jakarta: PT Bumi Aksara. 2010. p. 10.

5. Handoko TH. Manajemen Personalia dan Sumber Daya Manusia. Yogyakarta: BPFE. 2013. p.87

6. Hasibuan M. Manajemen Sumber Daya Manusia. Jakarta :Bumi Aksara. 2014. p. 228.

7. Hasibuan M. Manajemen Sumber Daya Manusia. Jakarta: Bumi Aksara.2016. p.219

8. Kadarisman M. Manajemen Kompensasi. Jakarta:Rajawali pers. 2012.p.275.

9. Kreitner R., Kinicki, A. Perilaku Organisasi edisi 9. Jakarta : Salemba Empat. 2014. p.132

10. Mardi. Sistem Informasi Akutansi. Cetakan kedua. Bogor: Halia Indonesia. 2014. p. 107
11. Kemenkes. Peraturan Mentri Kesehatan Nomer 12 Tahun 2013 tentang Jaminan Kesehatan [Internet]. Buletin Jendela Data dan Informasi Kesehatan. 2015 [cited 11 Agustus 2016]. Available from: www.kemkes.go.id/download/bulletin/

12. Robbins SP, Judge TA. Prilaku Organisasi. Jakarta: Salemba Empat. 2010. p. 157

13. Roszandi, Dasril. 2016. Oktober 2018 Jumlah Jaminan Kesehatan Nasional 203,28 Juta Jiwa. Artikel Tempo Available from::http://M. tempo. co/read/news/2016/10/24/060814/749/oktober2018-jumlah-peserta-jkn-203,28-juta jiwa

14. Siagian, Sondang P. Manajemen Sumber Daya Manusia. Bumi Aksara. Jakarta. 2012. p. 290

15. Sugiono. Metode Penelitian Kuantitatif Kualitatif dan R \& D. Bandung Alfabeta. 2011.p 106 